\title{
Tverrfagleg samarbeid i matematikk og mekanikk med aktiv studentdeltaking
}

\author{
A. Lunde ${ }^{1}$, L. Hansson ${ }^{2,3}$
}

\begin{abstract}
ABSTRAKT: Kva for fordelar kan eit samarbeid på tvers av emner ha? Erfaringar frå eit mangeårig, tverrfagleg samarbeid mellom forelesarar i matematikk og mekanikk blir presentert med fokus på nært samarbeid med studentassistentar. Målet med det tverrfaglege samarbeidet er å tydeleggjere for studentane samanhengar og synergiar mellom grunnleggande emne i ingeniørutdanninga. Studentane blir i begge emna oppfordra til å nå dette målet gjennom å ta ansvar for eigen læring gjennom aktiv studentdeltaking. Eit anna mål er at studentassistentane skal ta ei viktig rolle i å etablere eit felles læringsmiljø der studentane kan søkje hjelp i begge emna i studiet sitt. Resultatet er eit tverrfagleg samarbeid der studentar, studentassistentar og faglærarar opplever eit trygt, inkluderande og utviklande miljø på tvers av emner og institutt. Studentassistentane blir ei viktig brikke for å tilpasse, evaluere og vidareutvikle tilbodet om ein god og utviklande læringarena for studentane.
\end{abstract}

\section{INTRODUKSJON}

$\AA$ tydeleggjere for studentane samanhengar og synergiar mellom grunnleggande emne i ingeniørutdanninga kan vere ei utfordring. Dette er eit tema som også blir diskutert under uformelle møter, og idéen om å etablere eit tverrfagleg samarbeid mellom forelesarane for å oppnå dette kom (som andre idéar) under ein vanleg lunsj tidleg hausten 2016. Samarbeidet tar utgangspunkt i at studentane skal kunne spørje den same studentassistenten om hjelp i både matematikk og mekanikk. Det grunnleggande målet for samarbeidet mellom matematikken og mekanikken er å betre kvaliteten $\mathrm{i}$ undervisninga i begge emne gjennom inkluderande og aktiv studentdeltaking. Denne deltakinga blir også seinare meir aktiv ved at studentane må ta ansvar for eiga læring ved å jobbe med individuelle oppgåver og blir oppfordra til å aktivt spørje studentassistentane når dei «står fast» og treng hjelp for å kome vidare i oppgåva.

I ansvar for eiga læring la vi i dette samarbeidet opp til eit læringsmiljø der studentane skulle kjenne seg trygge og tore å stille spørsmål om oppgåver dei trengte rettleiing i for å kome vidare. Ei typisk utfordring både i matematikk og mekanikk er at studentane stopper opp i løysing av enkelte oppgåver og forstår at det er behov for hjelp til å kome vidare, men likevel ikkje stiller spørsmål. I tillegg er det heller ikkje lett å få tak i faglærar etter at undervisninga for dagen er ferdig, der det for mange også er eit stort steg å ta kontakt med faglærar. For å få fleire studentar til å ta ei meir aktiv rolle i studiet sitt er det derfor eit ønskje om å trekke inn studentassistentar som har eigen studieerfaring, er nær i alder til å motivere og i tillegg har tid til å skape eit trygt og godt læringsmiljø. Studentassistentar som nettopp har gjennomført emna sjølve vil enklare forstå og kjenne til utfordringane med emna. Fokuset på eit nært samarbeid med studentassistentar er dermed interessant for å etablere eit læringsmiljø med aktive og reflekterte studentassistentar. Det er essensielt å få studentassistentar som vil bidra med eigen studieerfaring og bidra med nye forslag for korleis få studentane meir aktive og ta ansvar for læring i sitt studie.

Under førebuinga til studiestarten hausten 2016 vart det kjapt etter idéen på lunsjmøtet bestemt å prøve å etablere eit tverrfagleg samarbeid mellom emna. Det tverrfaglege samarbeidet var tufta på å få eit felles фvingsopplegg som skulle vere til fordel for begge emna. Opplegget var ikkje bestemt på forhand av faglærarane, men vart diskutert i møte med interesserte studentar som kunne tenkje seg å vere studentassistentar. I etableringa av eit godt læringsmiljø var det svært viktig at studentassistentane var aktive med sine forslag før vi bestemte oss for kva opplegg vi ville gå for. Det resulterte i at avdelinga for ingeniør og realfag ved Høgskulen i Ålesund godkjente eit pilotprosjekt hausten 2016 med felles $\emptyset$ vingstimar der 5 studentar sa seg villig til å delta som studentassistentar. Pilotprosjektet fekk ei tildeling på 250 timar til disposisjon som inkluderte rettleiing og førebuingar til studentassistentane. 


\section{METODE}

Begge emna informerte studentane i oppstarten av semesteret om tilbodet om å få hjelp av den same studentassistenten i begge emna. Av praktisk tilrettelegging enda det opp med «studasshjelp»kl. 16-18 fire ettermiddagar (måndag - torsdag) i veka i 12 veker. Torsdagen var der to studentassistentar tilgjengeleg. Dette var eit tidspunkt på ettermiddagen der både forelesningane var over og faglærarane var gått for dagen. Studentassistentane fekk timefesta eit fast rom der studentane kunne stikke innom for å få rettleiing med oppgåver i begge emna. Studentassistentane hadde faste dagar dei sat på romma, men bytta innbyrdes om det var behov for det.

I etableringa av eit trygt læringsmiljø vart det tilsett studentassistentar som hadde tatt begge emna i tidlegare semester og som var kjent med både utfordringar og samanhengar mellom matematikk og mekanikk i første studieåret. Begge faglærarane hadde studentar i øvingstimane i emna frå tidlegare semester, og hadde dermed observert studentar som var ekstra flinke til å hjelpe sine medstudentar. Desse var dei mest aktuelle kandidatane til å bli oppfordra til å søkje om å bli studentassistentar i emna, men alle studentar kunne søkje. Dette medførte at studentane fekk hjelp av studentassistentar som hadde sosial og fagleg erfaring med samanhengen og synergien til dei to emna. Studentassistentane sitt faglege fokus var å hjelpe studentane ved rettleiing og ikkje løyse oppgåvene for dei eller gi dei fasitsvar.

I pilotprosjektet var det jamlege oppfølgingsmøter med studentassistentane i løpet av hausten og tilbodet om hjelp frå ein studentassistent vart nytta av fleire studentar, men ikkje alle. I oppfølgingsmøta vart det diskutert korleis få endå fleire studentar til å bli meir aktive med å stille studentassistentane spørsmål. Studentane som nytta seg av tilbodet var godt fornøgd med hjelpa av studentassistentane, og det var også faglærarane. Det tverrfaglege samarbeidet fekk dermed midlar til å fortsetje våren 2017 sidan mekanikken gjekk over to semester, og det var eit nytt matematikkemne som overtok om våren med same faglærar.

Hausten 2017 vart det tverrfaglege samarbeidet i dei to emna vidareført med ny forelesar i mekanikk etter at den førre gjekk av med alderspensjon. Det tverrfaglege samarbeidet vidare er i regi av artikkelforfattarane, og i vidareutvikling av samarbeid mellom emna har også ansvaret for eigen læring til studenten stått endå meir sentralt . Og i vidareføringa av dette samarbeidet er studentassistentane framleis ei viktig brikke for å tilpasse, evaluere og vidareutvikle tilbodet om ein god felles læringsarena.

Med auka trykk på romkapasiteten, så vart det i oppfølgingsmøta foreslått å prøve å gi hjelp i eigen plassering som på studentlab og på fellesareal. Dette vart gjennomført, men tilbodet vart kontinuerleg evaluert, og etter vurdering av oppmøte så var det enklare å spørje studentassistentane om rettleiing når dei var på eit eige rom. I dag er «studassane» $\mathrm{i}$ eit undervisningsrom med tilgang til smarttavle og bruk av digitale verktøy som Blackboard Collaborate Ultra og OneNote. Dette undervisningrommet ligg nær studentgrupperom og lesesal, og er døypt til «Studassplassen». Der er det mogleg å få hjelp av studentassistentar både digitalt og ved fysisk oppmøte, og dette tilbodet har blitt vidareutvikla til at andre studentar kan få hjelp i andre emner også på ettermiddagstid. Dette har skjedd med aktive studentassistentar med gode idéar som faglærarane har støtta opp om og søkt om felles midlar til. Midlane som har blitt tildelt har gitt støtte til mellom anna profileringsmateriale som roll-up, t-skjorter, infoskjerm om tilbodet på rommet og kaffe/te til studentar som kjem innom for å stille spørsmål på «Studassplassen».

\section{RESULTAT}

Ansvar for eigen læring gjennom det tverrfaglege samarbeidet har inspirert faglæarane til å ta $\mathrm{i}$ bruk individuelle oppgåver i øvingsopplegget. Med utgangspunkt i det tverrfaglege samarbeidet har det ført til bruk av digitale verktøy til obligatoriske digitale øvingar i matematikk og mekanikk. Studentane arbeider med individuelle oppgåver av same vanskegrad der studentane til dømes svarer ved hjelp av fleirval og/eller fyller inn svaret sitt. Begge emna stiller krav om rett svarprosent på oppgåvene på obligatorisk $\emptyset$ ving for å få øvingane godkjent og gir studenten ei tidsramme for kor tid øvinga må vere levert inn. 
Studenten må ta ansvar for eigen læring ved å vurdere korleis, kvar og når han lærer best. Det er ulike måtar å lære på (lese sjølv, lytte, jobbe sjølvstendig, samarbeide i grupper, søke rettleiing). Studenten kan ikkje kopiere medstudenten sitt svar, men må ta ansvar og jobbe aktivt med stoffet for å kunne ta til seg kunnskap. Vi stiller dermed krav for å gjere studenten bevist på kva slags læringsmåte som fungerer best for ho/han. Studentassistentane rettleiar studentane som før i arbeidet med oppgåvene.

Etter at Høgskolen i Ålesund fusjonerte inn i NTNU med dei Høgskolen i Sør-Trøndelag og Høgkolen i Gjøvik har emna endra seg i både matematikk og mekanikk. Men samarbeidet mellom matematikk og mekanikk er tatt vare på og bruken av digitale verktøy til obligatoriske digitale $\varnothing$ vingar er vidareført.

I tillegg har bruken av digitale verktøy medført at vi raskare kunne snu oss rundt i 2020 til å kunne bruke digital verktøy under koronaen. Kombinasjon av bruk av digital læringsplattform (Blackboard Collaborate) og nettbrett (OneNote på Ipad) gjorde at studentane kunne følgje undervisning som før i sanntid og delta under timen med chat eller lyd, notere frå OneNote-tavla og finne notatane lett etterpå. OneNote gir dei også eigne sider der dei kan kommunisere digitalt med studentassistentar og faglærarar ved å laste opp sine oppgåver. Nettbrett gir store fordeler til å teikne og forklare utan lange e-postar der matematikknotasjon er vanskeleg.

Tverrfagleg samarbeid har også resultert i eit semester der det var mogleg å få til felles øvingstimar med begge faglærarane. Der kunne studentane stille spørsmål til begge faglærarane og arbeide med begge emna samtidig, og studentane fekk ei aktiv deltakerrolle i kva emne dei ville jobbe med og vi var tilgjengeleg. Vi har også hatt studentassistentar til å vere med i øvingstimar, men det har ofte kollidert med studenten sin eigen timeplan.

\section{KONKLUSJON}

Det tverrfagleg samarbeidet presentert støtter oppom at ansvaret for eigen læring til studenten står sentralt. Tilbakemelding frå studentassistentane til faglærarane undervegs i semesteret er essensielt for å tilpasse, evaluere og vidareutvikle tilbodet om å skape ein trygg og god læringsarena for studentane. Ved at studentassistentane sjølve har tatt emna er dei viktige rollemodellar. Dei står også sterkare i å inkludere og tydeleggjere for førsteårs ingeniørstudentar samanhengar og synergiar i dei grunnleggande emna, og studentassistentane blir meir reflekterte og utviklar seg i sitt eige studie. «Studassplassen»er blitt ein felles læringsarena for læringsassistentar i fleire emner der studentar på tvers kan spørje om rettleiing. Eit miljøskapande tiltak for studentane. Til slutt må det nemnast at for faglærarane har det tverrfaglege samarbeidet vore viktig i pedagogisk utvikling gjennom auka kunnskap og refleksjon over aktuelle læringsformer.

\section{REFERANSAR}

Hansen,G. , Ringdal, R. (2018). Formative assessment as a future step in maintaining the mastery-approach and performance-avoidance goal stability, Studies in Educational Evaluation 56 , 59-70.

Nicol,D.J. \& Macfarlane-Dick,D. (2006). Formative assessment and selfregulated learning: a model and seven principles of good feedback practice, Studies in Higher Education, Vol. 31, No. 2, April 2006, pp. 199-218.

Meland,A.T. (2011). Ansvar for egen læring, Göteborgs universitet, ISBN 978-91-7346-703-2 .

${ }^{1}$ Institutt for KT og Realfag, NTNU,, Larsgårdsvegen 2, 6025 Ålesund, Norway, E-post: arnhild.lunde@ @ntnu.no ${ }^{2}$ Department of Ocean Operations and Civil Engineering, Faculty of Engineering, Norwegian University of Science and Technology
(NTNU), Larsgårdsvegen 2, 6025 Ålesund, Norway, E-mail: laha@ @ntnu.no

${ }^{3}$ Wood Science and Engineering, Department of Engineering Sciences and Mathematics, Luleå University of Technology (LTU), Forskargatan SE-931 87 Skellefteå, Sweden, E-mail: larsh@1tu.se 